\title{
Strategies of Climate Change Denial: The case of Thierry Baudet
}

\author{
Roelien van der $\mathbf{W e l}^{1}$
}

\begin{abstract}
This paper discusses different strategies of climate change denial and focusses on the specific case of Dutch politician Thierry Baudet. Much of the literature concerning climate change denial focusses on Anglo-American cases, therefore more research non-English speaking countries is necessary. The theoretical framework describes the state of the art concerning climate change denialism and its links to occurring phenomena in Western societies and politics such as posttruth and populism. Afterwards, by conducting a deductive analysis of Thierry Baudet's climate denialism in the Netherlands, a more thorough understanding of the different strategies proposed by Stefan Rahmstorf and Engels et al. is reached. Although all four categories are detected in Baudet's denialism, consensus denial seems to be the most prevalent. The analysis of his usage of the notion of a climate apocalypse, combined with the analysis of his specific focus on consensus denial, broadens the understanding of how climate change denial can relate to populism.
\end{abstract}

\section{Introduction}

On April 6th of 2016, a consultative referendum about an association agreement between the European Union and Ukraine was held in the Netherlands. This referendum was an initiative by a think-tank called GeenPeil together with a website that discusses current events called GeenStijl and the Citizens Committee EU. Although people seemed indifferent to the topic at first, the initiators managed to reach the level of 433.000 signatures necessary to ask for a referendum. $32.28 \%$ of people went to vote, and the eventual outcome was $61 \%$ of the votes being against the association agreement. However, the vote was ignored by the Dutch government. The law that enabled for a consultative referendum was adopted in 2015 and abolished in 2018 (Kiesraad, 2016; NPO, n.d.).

Out of dissatisfaction with this outcome, one of the frontmen Thierry Baudet, announced that he would start his own political party: Forum voor Democratie (FvD). Baudet studied history and law and has obtained a PH.D. in judicial philosophy. Besides his publications in these fields, he has also published two novels. FvD can be classified as a conservative party with the main aims to create a more direct form of democracy, a stronger national sovereignty especially within the European Union, stricter rules about immigration and, most importantly, break the existing party cartel. Baudet argues that the approximately 10.000 people who are part of the most established Dutch political parties value their own interests above those of the Dutch people. They exchange jobs amongst each other, creating an unfair power balance in the Netherlands. Baudet also argues that ideology-wise a cartel exists between the parties. Politicians make promises during the election-period, however, after these elections they let go of these promises relatively easily. He claims that politicians make agreements concerning the market of opinions, therefore contemporary politics constitute a cartel. Baudet argues that although voters might

\footnotetext{
${ }^{1}$ Roelien van der Wel received a bachelor degree in Arts and Culture at Maastricht University in 2019. At the moment she takes a Master in Public Administration with a specialisation in Economics and Governance at Leiden University. Contact: Roelienvdwel@gmail.com.
} 
have very different intentions for voting for one party or another, the mechanism of forming coalitions will always lead to the same outcome (NPO, n.d.; Forum voor Democratie, n.d.).

With these opinions Baudet has emerged as a new populist in Dutch politics. The meaning of populism as a phenomenon, has been discussed by many scholars (see Canovan, 1999; Laclau, 2005; Salmela \& Von Scheve, 2017; Stanley, 2008 \& Taggart 2004). Especially Cas Mudde (2004) has been a leading scholar in the field. He defines populism as an "ideology that considers society to be ultimately separated into two homogeneous and antagonistic groups, 'the pure people' versus 'the corrupt elite', and which argues that politics should be an expression of the volonté générale (general will) of the people" (2004, p. 543). When populism is defined in this manner, it has two opposite worldviews: elitism and pluralism. These are the two issues Baudet argues to be fighting against. His anti-EU stance and the belief in the party cartel point towards anti-elitism, and his strong anti-immigration program and desire to implement laws in order to protect the Dutch culture, are indicators of his anti-pluralism (Forum voor Democratie, n.d.).

Baudet's anti-establishment stance is not only noticeable in FvD's party program, he also clearly demonstrated it in his style of debating in parliament. He started his maiden speech as a member of the parliament in Latin. In a debate about defence, he emerged in a military vest. The oddities that became apparent from video interviews, such as him bringing his piano from home into his workroom at the parliament and his appreciation of lavender from Provence, were generally received as being comical. However, some of Baudet's statements were deemed more controversial. On multiple occasions he referred to a need to return to a 'boreal' Europe, which generally refers to the originally white inhabitants of Europe. The comments Baudet made about women in one of his novels were not received positively either, and although in a tv-interview he argues the writings are fictional, he did proceed by defending Swiss pick-up artist Julien Blanc, whose main tactics are to make women feel insecure about themselves (de Vries, 2019; NPO, n.d.; de Volkskrant, 2017).

Despite these more negatively perceived occurrences, Baudet's message resonated well with the public. FvD entered the parliament with two seats after the elections on the 15th of March 2017. Not long after, in 2019, they managed to secure twelve seats in the Upper Chamber, which meant that they gained a shared place as the biggest party of the Netherlands (Kiesraad, 2019). During the Provincial Elections, which indirectly decided the outcome of the elections for the Senate, FvD mainly campaigned on two points: to stop mass-immigration and to eliminate the Climate Law (fvdnl, 2019). This Climate Law proved to be an important topic in these elections, and Baudet campaigned against it using a variety of arguments, ranging from the costs being extremely high to the unnecessity of it because science proving climate change is not conducted correctly.

This Climate Law was proposed by politicians from seven different political parties, among which the four coalition parties. The law aims to reduce the emission of greenhouse gasses by at least $55 \%$ before 2030, and 95\% before 2050 relative to 1990. It was proposed as a result of the Paris Agreement which was reached in 2015. In this agreement, the countries involved agreed to take measures in order to reach the goal to minimalise global warming to 1,5 degree by 2050 (Tweede Kamer de StatenGeneraal, 2016). The Climate Law was followed by a Climate Agreement, which included arrangements with the electricity industry, built environment, transport and agriculture sectors. All climate policy made by the Dutch government is based on reports of the Intergovernmental Panel on Climate Change (IPCC). This agency creates reports about climate change and its effects, under instructions of the United Nations (Rijksoverheid, n.d.). One of the possible reasons behind the creation of Climate Law and

\footnotetext{
$2 \mid$\begin{tabular}{l|l} 
Marble \\
Research \\
Papers
\end{tabular}
} 
Climate Agreement, was the pressure that came from Dutch citizens. Several climate marches had a great impact in showing the importance people attached to climate policy. On the 10th of March 2019, approximately tens of thousands of people were present at the climate march in Amsterdam. Especially the demonstrations by secondary-school students, modelled after the ones in Belgium, gained publicity. Likewise, in Germany, France and Sweden students marched for climate (ANP/Het Parool, 2019; Dujardin, 2019).

Although many people in Western societies have voiced their concerns about the climate, the opposition is also visible. Especially the election of Donald Trump as the President of the United States, shows that "climate deniers are anything but endangered species, particularly as country leaders" (De Pryck and Gemenne, 2017). In this paper, I will investigate this phenomenon of climate change denial, and take a closer look at this specific Dutch politician Thierry Baudet. Therefore the research question of this paper is: How does Thierry Baudet deny climate change, and in which ways does his denialism relate to the strategies used by other climate deniers as they are described in the main climate denial literature, especially the variants of climate denialism mentioned by Rahmstorf (2004) and Engels et al. (2013). There are multiple reasons as to why more research in this field is necessary, which are described by Karin Björnberg, Mikael Karlsson, Michael Gilek and Sven Hansson (2017). In their review of the scientific literature published in the last 25 years about climate and environmental science denial, they found that the reviewed articles were mainly written from an Anglo-American perspective. The five countries that had the most publications in the field were the United States, United Kingdom, Australia, New Zealand and Canada. The other represented countries did not include the Netherlands. Furthermore, Björnberg et al. explain that the denial of climate change and the science that supports it leads to climate policy that is heavily delayed and less-scientifically based. Therefore, any efforts to create doubt or uncertainty about the seriousness and scientific evidence of climate change is a serious problem. They emphasise the need to map and research climate change denial thoroughly because by doing so, more clarity about the strategies of climate denialists can be found. This, in turn, can lead to strategies to counter climate denialists and reach more scientific based climate policy. As there has been no research on climate change denial in the Netherlands, specifically of Thierry Baudet, understanding more about how he denies climate change and its scientific evidence will fill this gap in the existing research.

This paper will start with a theoretical framework, which includes an overview of the existing literature concerning climate change denial with a specific focus on different ways in which climate change can be denied, as explained by Rahmstorf (2004) and Engels et al (2013). In the theoretical framework, there will be additional explanation of the elective affinity between post-truth and populism and the notion of a climate apocalypse, since this is pertinent for the climate denialism of Baudet. The theoretical framework is followed by a deductive content analysis of Baudet's climate change denial. This analysis compounds five debates, one speech and one interview in which Baudet discusses climate change. After careful assessment of the data, I conclude that the most important part of Baudet's climate denialism is his distrust in the existing establishment, both scientific and political, which he expresses in terms of left-wing conspiracy theories and the notion of a climate apocalypse.

\section{Theoretical Framework}

\subsection{Climate change denial}


When discussing this topic, a clarification for the use of the term 'denialism' needs to be given. Multiple scholars within this specific field emphasise that the term is contested (O'Neill \& Boykoff, 2010; Björnberg et al., 2017). Throughout the literature, many terms can be distinguished, among which the most common are 'denial', 'contrarianism' and 'scepticism' (O'Neill and Boykoff, 2010, p.151). O'Neill and Boykoff argue that it is important to consider carefully which term to use, since the topic is highly politicised and using a term that seems belligerent could obstruct the highly needed political debates. Which term is most appropriate is dependent on the context in which it is used. Although denialism is contested because it could be considered to have a judgemental or moralising connotation to it, after careful consideration of the literature I have decided that this seems to be the best term to use within the context.

The context in which I chose to do so is the existence of a clear consensus on the state of the art of climate science. The measured temperatures in the past ten years have been higher than any records of the last centuries. The rise of these temperatures is due to a rising concentration of $\mathrm{CO}_{2}$ and other anthropogenic gasses. The rise of the $\mathrm{CO}_{2}$ concentration in our atmosphere is caused primarily by the burning of fossil fuels by humans (Rahmstorf, 2004, p. 78). Since this paper mainly deals with politicians and not the public, the assumption that they have plenty access to this information and therefore make a conscious decision to argue against it can be made. This is called 'motivated' denial (Björnberg et al., 2017, p.237). Because of the apparent existence of a certain motivation, the term denial will be used throughout this paper. Science denial is often defined as unwillingness to believe in the existing scientific evidence (Björnberg et al., 2017, p.237). In terms of what I consider to be climate science denialism, I will use O'Neill and Boykoff's definition of a climate contrarian. They use a definition by McCright (2007) and expand on that themselves, which leads to the definition of climate denialists as

"those who vocally challenge what they see as a false consensus of mainstream climate science through critical attacks on climate science and eminent climate scientists, often with substantial financial support from fossil fuels industry organisations and conservative think tanks. We expand on the connections between claims making and funding to also include ideological motives behind criticising and dismissing aspects of climate change science." (O’Neill and Boykoff, 2010, p. 151).

Kari De Pryck and François Gemenne (2017) argue that the phenomenon of climate-denial is as old as the first scientific consensus on anthropogenic climate change. One of the first studies on a counter movement was done by Aaron McCright and Riley Dunlap (2000). They researched conservative think-tanks in the United States that aimed to counter the endorsement of the Kyoto Protocol. Most of this criticism against climate science has been against the IPCC, the UN body that was responsible for the assessment of scientific data on climate change. This organisation has been under severe criticism since its founding in 1988.

Within climate change denial, multiple actors can be distinguished. In their review of the literature, Björnberg et al. (2017) identify six of them. Scientists, who are usually not part of the established scientists in the field and are not affiliated with any academic institution. Governments like the Howard administration in Australia and Harper administration in Canada that questioned the need to act against the reality of anthropogenic climate change. Political and religious organisations are also often mentioned in the literature as active actors denying climate change science, however this literature mostly addresses the American conservative establishment. Industry is often mentioned in relation to

\footnotetext{
Marble

4 Research

Papers
} 
the funding of climate science denial and the companies that do so are mostly active in oil or coal extraction. Research shows that the media deny climate science once there is a right-wing affiliation. Social media form an important part of the "echo chamber" of climate science denial. Lastly, the public is an important actor in climate science denial. Research has shown that in America, people identifying themselves as liberals and democrats are more likely to believe in global warming than people who identify as republican or conservative. Among conservative white males, denialists ideas are most common.

According to Björnberg et al. (2017) there are multiple factors that can be distinguished in the literature explaining the phenomenon of climate science denialism. Some authors focus on an explanation through psychological factors, which often means that they see climate science denial as a psychological defence against a perceived unsolvable problem or a cognitive dissonance. Sociological factors often refer to the social group that someone identifies with and where they acquire their information from, especially trusted partisan leaders (Häkinnen \& Akrami, 2014). When climate change denial is explained through values and worldviews, this often refers to ideological factors such as support of private property rights, support of free markets, conservative values or belief in capitalism but also religious beliefs. Lastly a factor that can explain denialism is organised denial. This relates to the interplay between several actors, spurred by conservative ideology, interests in fossil fuel or both.

Guy et al. (2014) investigate the influence of ideology on climate science denial. They found that especially people with a stronger tendency towards individualism than communitarianism and a stronger inclination towards hierarchy than egalitarianism were more likely to not believe in climate change. According to Guy et al., people who prefer individualism over communitarianism often prefer a weaker government and laissez faire economic system, therefore individualism seems to cohere with a neoliberal ideology. Patrick Kraft, Milton Lodge and Charles Taber underline the problematic nature of addressing climate change as an issue divided among partisan lines and address the need to create common understanding of the issues at hand (2015, p.131). According to Guy et al., providing people with more specific knowledge on the causes of climate change can counter the negative effects of ideology on people's beliefs. In their study of far-right climate change communication in Germany, Bernhard Forchtner, Andreas Kroneder and David Wetzel (2018) found that ideological factors can explain climate change denialism. However, they argue that other factors also seem to play an important role. One of them being the populist separation of 'the people' and 'the corrupt elite'. This relationship will be discussed in more detail in the section Post-Truth, Populism and Trump. Before that, I will discuss the different variants of ways in which climate change can be denied.

\subsection{Different variants of climate change denial}

Björnberg et al. (2017) explain that, in several of the surveyed articles, a distinction between three variants of climate change denial is made. This distinction originates from Stefan Rahmstorf (2004). The first category distinguished by Rahmstorf is trend denialism. The actors that fall into this category deny any kind of significant warming. They operate a few different theories as to why this is the case, the main one being that weather stations do not measure the temperature effectively because they are built in urbanised areas. However, as more scientific facts become available to laypeople, trend denialists become less common. Nevertheless, arguments supporting trend denialism can still be found in contemporary politics. A prominent politician who has used these arguments is Donald Trump. In his 
climate denialism, which is to a great extent communicated through the social media platform Twitter, a thorough misunderstanding of what the weather and what our climate exactly is becomes evident (Allen and McAleer, 2018). In his tweets he clearly states multiple times that he thinks that global warming is a hoax (Trump, 2014). And not just a hoax, Trump clearly emphasises the expenses that would be spent on this phenomenon that he argues not to be true.

The second category that Rahmstorf describes is attribution denialism. Attribution denialists do agree with the trend of climate change but question the effects of humans on these trends. Some also argue that the rise of $\mathrm{CO}_{2}$ in the atmosphere is not caused by humans. However, most of the attribution denialists believe that humans are responsible for the rise of $\mathrm{CO}_{2}$ but doubt whether humans are responsible for the warming of the earth. "This argumentation requires two premises: (1) that additional $\mathrm{CO}_{2}$ does not lead to discernible warming, and (2) that there must be other - natural - causes for warming." (Rahmstorf, 2004, p. 78). These other causes are often found in occurrences such as natural variation and solar cycles (Engels et al., 2013, p. 1020). An example of arguments that an attribution denialist might use can be found in the remarks of the former Australian Prime Minister Tony Abbott. In his book Battlelines he explains that climate change has always been happening, and that humans' influence on this phenomenon is unclear (De Pryck and Gemenne, 2017, p.122).

Rahmstorf's third category is the impact sceptics. They "accept anthropogenic climate change, but deny that it will have significant (negative) impacts on humans or the environment" (Björnberg et al., 2017, p. 235). According to Engels et al. (2014), reasons for this misestimation can be that the negative effects can seem too far away, both in time and in physical distance. Others might expect the weather to become nicer or that a shift of climate zones might cause better circumstances for agriculture or other economic activities (Rahmstorf, 2004; Engels et al., 2014). However, this form of denialism is not very common among prominent politicians. The uncertainty about the impact of climate change is more prominent in public opinion. For instance, Poortinga et al. (2011, p. 1021) found that among the British public, people were more prone to be impact sceptics than articulate the other two forms of denialism. And even among people who are generally convinced about climate change, uncertainty about the impact that it will have exists.

A later fourth category to this classification of climate denialists was added by Engels et al. (2013), namely consensus denial. They argue that studies have shown that there often exists a discrepancy between the consensus existing among climate scientists and the public perception about the existence of such a consensus. Contrarian politicians have used this public confusion to argue against big measures against climate change, often for political or ideological reasons (Lewandowsky et al, 2015). To do so, climate science deniers often reuse tactics employed by the tobacco industry. As De Pryck and Gemenne (2017) explain, the tobacco industry argued that there was no link between cigarettes and lung cancer. Climate denialists nowadays discredit science in a similar way, propagating that the scientific record is not settled. An example of this could already be found in the administration of former United States president George W. Bush. During the Bush administration, practices took place such as "censoring, suppressing and even dismissing federal scientists; altering, distorting and suppressing scientific findings for government reports; manipulating the government's science advisory system; and ignoring, distorting and selectively using scientific evidence in policy-making" (Dunlap \& McCright, 2010, p. 101).

As Engels et al. (2013) explain, these four forms of climate science denial can have negative effects on the process of effective policy making. Trend denialism can lead to the disagreement with any 
kind of policy against global warming. Attribution, impact and consensus denialism can lead to policies against a few specific issues, such as the building of higher dykes for the rising water of the oceans. However, the causes of climate change will not be tackled. Björnberg et al. (2017) recognise as well that organised science denial can influence environmental policy processes. "Empirical studies from other policy fields confirm that organised science denial perpetrated by actors with considerable political or economic capital can affect how society responds to serious threats or problems" (Björnberg et al., 2017 , p. 230). Once these politicians are in power, they can utilise different strategies in order to divert public attention from policies that would counter climate change such as the appointment of climate deniers in high functions of scientific agencies, cancelling scientific panels or programmes and reorienting or cutting the funding of research. Trump has done similar things like cutting funding for the IPC, UNFCCC and the Green Climate Fund, abolishing the Clean Power Plan and promoting the combat against other environmental issues over the need to fight climate change.

Research about commonly used techniques among climate change denialists has shown that denialist techniques are not commonly exclusive. One actor can use multiple techniques in order to, for instance, appeal to a wider audience or to show that there are multiple reasons why there should not be climate change action (McKie, 2018, p.305).

\subsection{Post-truth, Populism and Trump}

The Oxford dictionary chose post-truth as the word of the year for 2016, defining it as "relating to or denoting circumstances in which objective facts are less influential in shaping public opinion than appeals to emotion and personal belief" (Oxford University Press, 2017). De Pryck and Gemenne relate Trump's climate denialism to the rise of a post-truth context. Silvio Waisbord (2018) argues truth has always been an obscure concept tied to someone's background and perception of the world. In a similar manner, deceptions and deliberate distortion of facts has always been part of politics, concepts such as 'fake news' and 'alternative facts' are no pointers of new phenomena. However, post-truth appears to be a completely new phenomenon. Post-truth communication is not about the relativity of facts, but "lays bare the crashing down of the modern, rationalist model of a well-defined, accepted model of truthtelling as a shared communicative enterprise rounded in reason and science" (Waisbord, 2018, p.3). Truth has become indefinitely contested in all forms. Therefore, all aims to articulate any facts about the world can be countered by arguing that it is partial.

Because of these-post truth communications, the occurrence of a single 'regime of truth' has become impossible. 'Regime of truth' is a term coined by Foucault in 1975 and "refers to accepted rules and practices established to define knowledge and regulate discourse" (Waisbord, 2018, p.8). Waisbord argues that the crumbling of this 'regime of truth' can be distinguished in medicine and science, where the public often denies scientific models and expertise. The rise of social media has supported this phenomenon, since there are no institutions that control information flows and untrue information is shared and sustained in online echo chambers.

Waisbord argues that an elective affinity between post-truth communication and populism exists. The idea of an elective affinity, originally formulated by Max Weber, means that there is a close relationship between two phenomena that is not necessarily causal. The relation between the two can be found in their similarities. Waisbord sees these similarities mainly in populism's rejection of the possibility of the truth. The reason for this is its inherent anti-elitism, and the argument that both 'the people' and 'the elite' have their own version of the truth. Therefore, their truth is based around the 
"reaffirmation of a dualistic narrative that remains undisputable regardless of actual events" (Waisbord, 2018 , p. 10). Because of this their version of the world can never be corrected by critics, because there are no facts that will be considered by the populist to form a legitimate counter-argument. If scientific facts are proposed against the simplistic view of populists, these will be dismissed as 'elitist manoeuvres' (Waisbord, 2018). Therefore, institutions of scientific facts are always political at the same time to populists.

In these post-truth communications, Waisbord argues, two specific styles can be distinguished. For this argument, he uses Harry Frankfurt's not so delicately phrased notion of 'bullshitting'. Waisbord argues that Trump can be classified as a 'bullshitter', which is a person who does not care about what might constitute the truth. To Trump, facts do not matter. Trump's personal beliefs seem to weigh heavier than scientific evidence and his opinion seems to be largely influenced by the economic consequences of the effects of climate change. The argumentation he provides is often a blend of lies, personal beliefs and conspiracy theories and his information is often not provided with available sources. Facts, to Trump, have become simply unnecessary (De Pryck and Gemenne, 2017). This emphasis on the emotional side of politics is often present with populists. Margaret Canovan (1999) argues that populism actually emerges at the intersection between democracy's redemptive face and pragmatic face. These two faces of democracy are equally important in its functioning, and a balance between the two is necessary. The redemptive side of democracy concerns the promise that salvation can be reached through popular power. It is the anti-institutional side of democracy, which is more concerned with personal politics. The redemptive side of democracy gives people hope and a vision for the future. On the other side, the pragmatic face of democracy concerns its aim to cope peacefully with conflicts and regulate power through institutions. Populism, according to Canovan, emerges when a gap exists between these two sides of democracy and people start to feel alienated from the system that should allow them to govern themselves. This is a source of populism's anti-elitism. When the ruling elite becomes too pragmatic and does not focus on presenting a redemptive vision of the future anymore, "populists tent to move on to the vacant territory, promising in place of the dirty world of party manoeuvring the shining ideal of democracy renewed" (Canovan, 1999, p. 11).

\subsection{The Notion of the Climate Apocalypse}

In their efforts to criticise the elite, populists often turn to conspiracies and apocalyptic thinking (Eatwell \& Goodwin, 2018). Eatwell and Goodwin mention for instance Trump's claims that Washington is a swamp consisting of a network of bureaucrats trying to undermine his presidency. Similarly, accusations towards the elite could be seen in Nigel Farage's Brexit campaign. Victor Obán in Hungary also blamed liberal politicians in the EU of flooding Hungary and Europe with Muslim immigrants and refugees. Eatwell and Goodwin argue that these conspiracy theories have been part of populist rhetoric for a long time, and quote historian Richard Hofstadter who already wrote in the 1960s that

"The paranoid spokesman sees the fate of conspiracy in apocalyptic terms - he traffics in the birth and death of whole worlds, whole political orders, whole systems of human values... Like religious millennialists he expresses the anxiety of those who are living through the last days and he is sometimes disposed to set a date for the apocalypse." (as cited in Eatwell \& Goodwin, 2018, p. 49).

\footnotetext{
Marble

8 Research

Papers
} 
Forchtner et al. (2018) found arguments of left-wing conspiracy-theories and accusations of eco-dictatorship and a totalitarian character of 'ecologism' in their analysis of German right-wing climate denial communications. Their research indicates "a populist discontent with mainstream scientists who contribute to a political project by a corrupt elite, a project that harms the general will of the 'pure people'" (Forchtner et al, 2018, p. 596). The left was blamed of being misguided and not understanding what was happening. However, the right-wing magazines spoke of themselves, the in-group, as holding obvious truths. They also found that part of the reviewed articles presented the left as "engaging in a blind and zealous, quasi-religious belief in climate change" (Forchtner et al, 2018, p.597). According to Björnberg et al. (2017), this focus on denying climate science by using conspiracy theories, was not seen in the lobbies by the tobacco industry.

These references to religion are not unusual. Research shows that the idea of a 'climate apocalypse' has played a part in the political debate surrounding climate change before. An apocalypse refers to "The complete final destruction of the world, as described in the biblical book of Revelation" (Oxford Dictionary, n.d.). The idea of an apocalypse has had a long history in Christian and Jewish faith and was seen as a sign of God's intervention in the world and would reverse the world's existing order. According to Stefan Skrimshire (2004) both climate campaigners and deniers use the climate apocalypse in their vocabulary. The dramatic images and narratives of Christian apocalypse work well for climate activism. Several movies and campaigners have used visuals such as hot summers and giant floods to get their message across (Skrimshire, p.244).

Chris Methmann and Delf Rothe (2012) argue that climate change is inherently linked to a logic of apocalypse. They argue that the United Nation Framework Convention on Climate Change (UNFCC) for instance, in its discourse, changes climate change from a human induced phenomenon, to a dangerous other. According to Methmann and Rothe the logic of apocalypse is portrayed in multiple ways when it comes to climate change, for instance the portrayal of climate change as a global war. They also emphasise that climate change is a 'threat multiplier', because it affects all parts of society all over the world. Humanity is portrayed as the collective victim of this threat.

Thus, for climate activists, the notion of the climate apocalypse is used as a means to shock the public, but "by contrast, climate sceptics often accuse media and politicians of adopting precisely this trope of biblical apocalypse. Their claim is that by so doing, activists enforce a political agenda by means of fear rather than rational dialogue" (Skrimshire, 2013, p.239). He mentions the example of the British Institute of Economic Affairs (IEA), which was a coalition of oil advocates and conservative economists. They published a report that "accused the 'alarmist' language of institutional religion' to justify 'centralised' illiberal policies (policies that would curtail 'sovereign freedoms' of the individual)" (Skrimshire, 2013, p.239). Their criticism was mainly directed towards the IPCC and its scientists, who were accused of using apocalyptic and alarmist rhetoric. Swyngedouw argues that the core of climate politics, in its apocalyptic thinking, is inherently against traditional democracy, in the sense that it is not about a positive vision for the future, but is grounded in negativity, "without promises of redemption, without a positive injunction that 'transcends'/sublimates negativity and without proper subject" (Swyngedouw, 2010, p.224).

In the climate debate this problem-focused governance that can spur from apocalyptic thinking, according to Erik Swyngedouw (2010), especially manifests itself in a high focus on $\mathrm{CO}_{2}$ stabilisation. He argues that the environmental politics utilise populist manoeuvres in the debates about the future of an environmental catastrophe. Firstly, climate change is portrayed as a universal humanitarian threat, 
therefore making a clear distinction between 'the environment' and 'the people'. The people are constituted as universal victims against a greater threat, often portrayed as $\mathrm{CO}_{2}$. Even though the threat will have different impacts in different places, people are mobilised to tackle climate change homogeneously, making no distinctions between race, gender, socio-economic factors, etc. Secondly, a reduction of $\mathrm{CO}_{2}$ in the atmosphere should lead back to an idealised point in the past. $\mathrm{CO}_{2}$ is externalised as an enemy, as an intruder within the system. It is not the existing structure and power systems that are wrong, but an outside phenomenon that is intruding this system. The policy that is being made, as a result, focusses on the extinction of this enemy from the system. This policy should be formed through the ideal form of governance, in which the people know best and govern themselves with help of a neutral scientific technocracy.

Now that an overview of the literature and important theories has been given, an analysis of Baudet's climate change denial can be conducted. In the next section I will explain how the four categories that were extracted from the literature of Rahmstorf (2004) and Engels et al. (2013) and the notion of the climate apocalypse are used in order to conduct a deductive content analysis. By conceptualising Baudet's climate denial in such a manner, I can discover how his strategies relate to what has been found in the literature concerning climate change denial up until recently.

\section{Methodology}

In his analysis, Rahmstorf finds that climate science denial, by all possible actors, can be distinguished in three categories. Although Rahmstorf originally only mentions lobbyists, scientists and laypeople as the actors active in denialism, as mentioned by Björnberg et al. governments and political organisations have also become important actors within climate denialism. De Pryck and Gemenne emphasise the role that denialist politicians have in the diversion of public attention from the problems that will be caused by climate change. Since Rahmstorf's categorisation can be applied to any kind of denialist, this paper will utilise his categorisation and the added category by Engels et al. and apply it to Baudet's climate science denial. As a fifth category, climate apocalypse will be tested, since it seems to be an important part of his denialism. Hopefully this analysis can shed light on the usage of the climate apocalypse and left-wing conspiracies in a non-Anglo-American context and expand the knowledge about the topic.

In order to do so, a deductive content analysis will be conducted. This method is described by Satu Elo and Helvi Kyngäs (2007). They explain that the aim of content analysis is to conceptualise a phenomenon. In this case the phenomenon is Baudet's climate science denial and the conceptualisation would be which strategy or strategies he uses in order to conduct this denialism. The method has been used in the past to analyse different forms of content, such as political speeches and newspaper and magazine articles. It is both useful to describe and to quantify a phenomenon. By using the existing categories, a quantitative description of which strategy is most used can be made. However, by also qualitatively describing how Baudet argues in favour or against certain aspects of these pre-made categories, a deeper understanding of these categories can be gained.

A deductive analysis is used when the researcher wants to test a previous theory in order to, for instance, compare categories to each other. A content analysis exists out of three distinct phases: the preparation phase, organisational phase and reporting phase. For the preparation phase, the unit of analysis needs to be selected. In this case, the unit of analysis is Thierry Baudet's discourse about the topic of climate change. Although he does post on social media, these posts never include thorough argumentation of his opinions. Therefore social media content does not serve well in order to completely

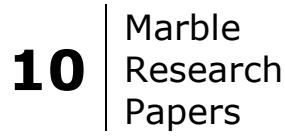


comprehend his climate change denialism. For this reason, the decision was made to focus solely on speeches and debates, in which he states clear arguments. This leads to a unit of analysis consisting of one speech, one interview and five debates.

The speech, called 'De uil van Minerva' (Minerva's Owl), was given by Baudet after his party Forum voor Democratie (FvD) secured twelve seats in the Senate. For the debates, a search of all debates in parliament since the inauguration of FvD with the search word 'climate' and as speakers 'Thierry Baudet' was done and the relevant ones were picked. The first debate concerns the Climate Law and was conducted on the 6th of December 2018 with a continuation on the 19th of December 2018. The second debate concerns the Climate Agreement and took place on the 5th of February 2019. The third debate concerns the same Climate Agreement, but focusses on the calculations of the expected consequences by the Planbureau voor de Leefomgeving (Netherlands Environmental Assessment Agency, PBL) and the Centraal Planbureau (Bureau for Economic Policy Analysis, CPB). The fourth debate did not take place in parliament but in the tv-show Nieuwsuur on the 13th of March 2019 in response to calculations of the PBL and CPB. The fifth debate concerns the briefing by the IPCC of Dutch politicians concerning global warming, and took place on the 7th of February 2019. The interview that will be analysed was in relation to this briefing and Baudet's reaction to what was said, it was published on the same day.

For a content analysis it is important that the researcher firstly immerses herself in the data. Therefore, the debates, interview and speech were watched multiple times before starting the analysis. In order to do the analysis, multiple deductive analysis matrixes were created. Each matrix included the five categories: trend denial, attribution denial, impact denial, consensus denial and climate apocalypse respectively. The sources will be analysed in chronological order, so that an alteration in strategy can be easily observed and reported. The last step of the organisational phase is the actual organisation of the data. In a deductive content analysis this means that all data corresponding with, or disproving the categories is put within an analysis matrix. For each source two matrixed are used, one that includes the data that agrees with the categories, and one that counters them. In that way, a fair analysis can be done in which all data are taken into account.

Elo and Kyngäs explain that a decision needs to be made whether only the manifest content will be analysed, or the latent content as well. When analysing the latent content, things such as silence, sighs, laughter, posture, facial expressions, etc. are taken into account. Since all the data for this research are spoken and can be accessed in video format, an analysis of the latent content seems to be useful. Although there is a risk, since a high level of interpretation comes into play, the latent content is important to such an extent that I have chosen to include it in the analysis.

\section{Analysis}

In this section, the results of the content analysis will be discussed. First, attention will be paid to the four categories of Rahmstorf (2004) and Engels et al. (2013). Afterwards the usage of the notion of climate apocalypse will be discussed in more detail.

\subsection{Analysis of the categories by Rahmstorf and Engels et al.}

The first category was trend denial. As was already explained by Rahmstorf and Engels et al., this category is not very commonly used, and it could also not be detected much in Thierry Baudet's general 
discourse. In the parliamentary debate about the Climate Law, Baudet does say that "I do not believe that there is a climate problem" (Baudet, 2018a). In the same debate he also states that there is still a lot of unclarity about whether climate change is actually happening and emphasises the difficulty to measure this, since there are only satellite measurements since 1979. Since there are no exact measurements from before that year, a greater trend cannot be officially detected. However, in later debates Baudet did not make these kinds of comments as much anymore and started to focus more on the other possible arguments against the climate policies.

Therefore, much more data could be found within the attribution denial category. Baudet emphasises that the climate has always changed and that the extent to which it is doing so is unclear. In his interview concerning the climate march, he explains that he feels bad for children because he thinks that they are told a wrong story (2019b). This story, told by the alarmists as he calls them in other debates, contains the idea that temperatures suddenly started to rise after fossil fuels were discovered. Baudet emphasises that the temperature on earth has always fluctuated and often brings up that there have been ice ages and warmer periods. However, according to him the link between a rise of $\mathrm{CO}_{2}$ and a warmer climate cannot be made. Therefore, he strongly speaks out against policy focused on the reduction of $\mathrm{CO}_{2}$ emissions by the Netherlands. This for instance became clear when a member of the Christian Union party acknowledged that $\mathrm{CO}_{2}$ is not the only existing problem concerning the climate, and Baudet answered by saying "well then, can we stop the obsessive reducing of it, when other countries are not doing so" (Baudet, 2018b).

The argument that other countries are not doing much is often used by Baudet. He claims that the Netherlands is such a small country that the efforts in reducing $\mathrm{CO}_{2}$ would not be very useful anyways. In the debates he often goes back to a few calculations, where the origins remain unclear of. According to these calculations, if the Netherlands would execute all the government's plans as stated in the Climate Law, the warming of the earth's temperature would be reduced by $0.00003^{\circ} \mathrm{C}$ and if all the countries that made promises in the Paris agreement would execute all their plans it would limit the warming of the atmosphere by $0.05 \%$ globally. Therefore, according to him, obsessive reduction of $\mathrm{CO}_{2}$ would not be productive in order to reduce the effects of climate change. He also emphasises the effect of other natural processes on the change of the climate such as clouds, volcanic activity, el niño's, the sun and what is happening in our atmosphere.

Apart from denying the significant effect of $\mathrm{CO}_{2}$ emissions on the climate, Baudet also emphasises the positive effects of a $\mathrm{CO}_{2}$ rise on the environment. These arguments that he puts forward fall within the category of impact denialism, because by emphasising the positive effects of climate change, he undermines the actual impact. For instance, after arguing that the influence of $\mathrm{CO}_{2}$ on the rising temperature on earth is unclear, he mentions that $\mathrm{CO}_{2}$ is making the earth ten to twenty percent greener. These are, according to him, the

extreme positive effects of $\mathrm{CO}_{2} . \mathrm{CO}_{2}$ is oxygen for plants, and for plants and trees on earth it is the same way as it is for humans on the top of the Himalaya. They are... [takes a deep breath]... continuously searching for $\mathrm{CO}_{2}$. (Baudet, 2018b, Italics indicate action).

In another debate he makes the same point, saying that the increase of $\mathrm{CO}_{2}$ makes the earth more pleasant for plants and trees and that therefore more plants and trees will grow. Apart from the positive effects of $\mathrm{CO}_{2}$, Baudet also minimises the negative effects of climate change. He emphasises

$12 \mid$\begin{tabular}{l|l} 
Marble \\
Research \\
Papers
\end{tabular} 
that, according to him, the temperature on earth has only raised a little. In the debate about the climate law, he continuously shows graphs that, according to him, show that there is no increase in drought, no difference in precipitation on land nor on sea, no change in the amount of hurricanes and no increase of the amount of damage because of extreme weather in comparison the economy. Also, the number of victims of extreme weather has decreased according to him. In a later debate he mentions that if people have to flee their homes because of changes in the climate, he would not consider them refugees, therefore de-emphasising the serious effects climate change will have on people. This fits with FvD's general standpoints concerning migration.

The last category, and probably most evident in Baudet's climate change denial, is consensus denial. The reason this one is so evident is that it appears to be the underlying logic of all the arguments he uses in the other three categories. The first three build upon each other in the sense that he uses a constructive logic: climate change is not really happening because the climate always changes, however, even if the climate is changing differently from before, it cannot be linked to a human induced rise of $\mathrm{CO}_{2}$, however, even if humans are responsible for a rise of $\mathrm{CO}_{2}$ in the atmosphere that influences the environment, this influence is not very negative anyways. The underlying logic of all these arguments, is that Baudet does not trust the scientific arguments that prove that a trend exists, that humans heavily attribute to this trend and that it will have a severe negative impact on the world. He claims that, as he is a scientist himself, he has the ability to carry out a critical methodology. Therefore, he does not believe that there is a worldwide consensus. He says that "that whole part about there being $97 \%$ consensus is nonsense" (Baudet, 2018a), and that it stems from one specific article. However, when confronted with this on the 15th of March 2019 by politician Rob Jetten who says "mister Baudet has denied climate change for a very long time, even though $97 \%$ of climate scientist agree" (Jetten, 2019d), Baudet answers by saying that "That is nonsense" (Baudet, 2019d).

In the continuation of the debate concerning the Climate Law on the 19th of December, an IPCC-report became a topic of discussion. As mentioned in the theoretical framework, the IPCC has been under attack ever since its founding in 1988. In this discussion, Baudet questions the academic methods of the researchers of this organisation. He claims that an opinionated research question was used, since it asked what the impact of $\mathrm{CO}_{2}$ on the climate was, and did not ask about the influence of all types of factors. He claims that therefore the impact of $\mathrm{CO}_{2}$ on the climate and which other factors could play a role is unclear. He continues with the argument that there is no scientific consensus anyways, because no consensus was held among scientists, only international conferences that both people who agreed and people who were doubting could attend. He claims that the consensus mentioned by politician Eppo Bruins, with whom he is debating, simply does not exist.

In the technical briefing about 'Global Warming of $1.5^{\circ} \mathrm{C}$ ' from the IPCC, he claims that the models that the IPCC uses are too focussed on $\mathrm{CO}_{2}$, and asks whether an adjustment in the models could perhaps lead to a different view of the effect of $\mathrm{CO}_{2}$ on climate change. In response to this, the scientist Bart Strengers, who works for the Planbureau voor de Leefomgeving ( $P B L$ ), explains that there is a range of models and that an adjustment would probably lead to a more negative outcome. In response to this, Baudet argues that, in response to this insecurity, "you could also say that means that it is useless to do anything about it anyways ... maybe it will become 20 degrees warmer here, I mean, if it is that uncertain, then maybe we should just make our dykes higher. Instead of all that madness" (Baudet, 2019a). 


\subsection{The Role of the Notion of Climate Apocalypse}

As is explained in the introduction, Baudet's party Forum voor Democratie was founded because of dissatisfaction with the existing political and cultural situation. As Baudet says himself in the victoryspeech of the Provincial Elections (2019e), he would have not become a politician, if he had not felt that it was absolutely necessary. In the speech he explains that one of the reasons why he felt this necessity was a 'climate-heresy'. He argues that there was a vacuum in the Dutch culture and spirituality, and that this lack in a belief in something was filled by a new form of religion or political theology. He claims that the mainstream political parties in the Netherlands, the 'party cartel', have had no faith in anything and no vision for the future for a very long time. However, now they believe in a new demigod: transition. He argues that the parties are willing to spend 1000 milliard euros on transition, "in the form of windmills, heat pumps, solar panels and other completely unprofitable projects that will not bring us anything, that will not bring the planet any further but will cost us extreme amounts of money and punish us very much" (Baudet, 2019e). The belief that is at the basis of all these costs, Baudet argues, is a "deluge belief". Therefore, implicating a religious, apocalyptic imaginary.

The same idea was put forwards by Baudet in the debate with politicians Jesse Klaver of GroenLinks and Rob Jetten of D66. In that debate he claims that the idea of climate change is dubious and that "the rising sea-levels are actually a secularised Christian story of Noah's ark and the sea that comes to punish us for our sins. So there is a psychological mechanism behind the reason why people believe in it so much." (Baudet, 2019d). In the speech he argues that this psychological reason is grounded in guilt and self-hatred. He calls this oikophobia, a phenomenon which relates to a hatred of the self or of the home and which he wrote a book about in 2013. Thus, the climate apocalypse is used as a means of blaming the elite that they are exaggerating the effects of climate change and that their aim to fight against it unitedly comes from a shared feeling of, unnecessary, guilt. In this way Baudet uses a similar tactic as the one seen by the Institute of Economic Affairs. He blames the established parties of using alarmist language and apocalyptic visions of the future. This relates to Canovan's explanation of modern democracy functioning in between its redemptive and pragmatic side. Baudet accuses the establishment of having an apocalyptic notion for the future and presents himself as the saviour with a more redemptive vision for the future.

By talking of a climate apocalypse, Baudet discredits the existing establishment. He calls them alarmists that make up sectarian apocalypse fantasies. But he also argues that current science and education has been indoctrinated by the untrue hoax-story, created by the left-wing elite. He even argues that aims of climate actions are secretly just disguised left-wing policies. "They are searching for an excuse to regulate our whole life. To gain control over all aspects of society. It is a watermelon: it is green from the outside, red on the inside. It is socialism with a new jacket." (Baudet, 2019d).

\section{Conclusion}

From the literature concerning climate change denial, it can be deduced that climate change denial is often related to a conservative, right-wing ideology and is often conveyed by white men. In this respect, Thierry Baudet fits the picture of a climate denialist. However, from this paper can be concluded that his strategies differ from, for instance, Donald Trump. His focus on him being an intellectual, but also his usage of the notion of a climate apocalypse are characteristics of both Baudet's climate change denial, but also his populism. 
From the deductive content analysis, it can be concluded that Baudet makes use of all four denial variants of climate change described by Rahmstorf (2004) and Engels et al. (2013), trend denialism, attribution denialism, impact scepticism and consensus denial. The way he uses these strategies are mostly related to the last category, and a constructive argumentation can be detected. Baudet's denial of anthropogenic climate change that will have negative effects, is rooted in his disbelief of the scientific consensus proving this. This can mostly be seen in his accusations against the IPCC for conducting faulty science, something that has been done by different climate denialists ever since the founding of the institution in 1988.

In this science denial, Baudet argues that the established politicians and scientists do not understand climate change as well as he does. He makes claims about their methods and findings and argues that he can do so because of the critical methodology he learned as an intellectual. He brings his own graphs and calculations to parliament. From his own findings, he argues that the established parties are being alarmists. He says that they are spreading an untrue message and by doing so indoctrinate education and science with a left-wing ideology. This message, according to Baudet, takes the form of a climate apocalypse, a deluge belief which is supposed to fill the void of belief of the established parties. This criticism seems to be part of his populist rhetoric, which he mostly voices in terms of aiming to break the party cartel. For instance, the climate law that he criticised, was proposed by seven different parties, among which the four coalition parties. Thus, by criticising climate change action, he criticises the establishment and their unity of ideas.

Trump is often mentioned in the literature as a typical climate denialist. As a populist who makes use of the post-truth narrative, Trump claims that climate change is a hoax. He argues that from the weather can be deduced that climate change is not happening. In his argumentations he has a total disregard of any regime of truth. Baudet, on the other hand, does still care about truth to a certain extent. He emphasises the fact that he is an intellectual and that truth exists, but that the established political parties do not see it. Whereas Trump seems to mainly aim towards creating confusion about climate change, Baudet wants to prove that he is right and that the established parties are wrong. Therefore, his climate change denial and populism are not rooted in post-truth, making him a somewhat atypical populist.

Knowing that these are the strategies that Baudet uses to deny climate change, and the knowledge that his message resonates well with the public, can help to gain some insights into what might be useful in terms of countering him. Firstly, since Baudet's criticism towards the elite is about their negative view of the future, he criticises the current redemptive side of Dutch democracy. Apparently, the established political leaders do not create a secure enough vision for the future, and therefore people like to hear Baudet's message because he argues that climate change is not as detrimental as we think, and that spending large amounts of money to counter it is unnecessary. If the established political parties are able to emphasise their redemptive vision of the future, this might resonate better with the public. Secondly, the fact that Baudet is able to come to debates in parliament with his own calculations and graphs is problematic. Even if these calculations are debunked afterwards, videos of the debates already circulate on the internet. The echo-chamber of social media makes that people believe these statements made by Baudet. This creates false beliefs about climate change among the public.

This paper still shows some limitations. The usage of the deductive content analysis, especially the analysis of latent content, means that a certain level of interpretation will have most certainly played 
a role. Therefore, further research in this field to gain more structural data about multiple politicians is necessary. As can be seen in this paper, climate denialism is most certainly present in non-AngloAmerican situations, and more research would therefore lead more knowledge about the field. Analysing more politicians from different countries can hopefully lead to more strategies in order to counter climate change denial.

Although the usage of the notion of a climate apocalypse could be considered to be a new category on its own, it could also be considered part of consensus denial, since it is a form of criticising the existing consensus among the political and scientific establishment. This content analysis shows that left-wing conspiracies such as using the notion of a climate apocalypse is an important strategy in denying climate change. Using conspiracy theories in science denial was not yet detected before climate change denial. Therefore, this addition, of the analysis of a politician who uses these means in parliamentary debates, is a valuable new addition to the existing literature. 